\title{
Benchmarking Strategy of Vocational High School in North Bengkulu
}

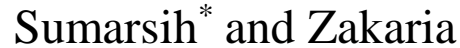 \\ Magister of educational administration, University of Bengkulu \\ *Corresponding author. E-mail: sumarsihasiih@gmail.com
}

\begin{abstract}
The goal of this study was to identify strategies for improving the quality of vocational high schools in a competitive way. A qualitative definition was used in the research approach. Principals, instructors, and students were treated as data sources. Data collection was using the observation process, interviews, and documentation. Study of data was using the model from Milles and Huberman. The results showed that the benchmarking strategy to improve the quality of schools was carried out including beginning with environmental analysis to identify internal strengths and weaknesses, external challenges and opportunities, followed by setting school quality goals, establishing a quality assurance team, creative teacher learning training, class competition, apprenticeship and partnership programs, extracurricular activities optimization, student character promotion, teamwork, and awards for exceptional teachers and students.
\end{abstract}

Keywords: Benchmarking, Strategy, Policy, Quality of high school.

\section{INTRODUCTION}

It is a priority for every country to improve the standard of education. Each unit of education strives to improve the quality of the delivery of education services to its consumers. Every effort made is intended to enhance so that graduates have quality skills according to the predetermined goals, because in the grobal era, quality graduates are a skill requirement. To provide consumers with loyalty, quality assurance is a must. Each school has a strategy to illustrate the use of different techniques, one of which is by benchmarking [1]. Strategy is the long-term strategy of a company to balance the school's internal strengths and vulnerabilities with external possibilities and challenges to retain a competitive advantage.

Article 4 of Government Regulation No 19 of 2005 on National Education Standards notes that national education standards aim to ensure the quality of national education in the sense of educating the life of the nation and shaping with integrity the character and civilization of the nation. Through guaranteeing the quality of national education, the government is required to boost the quality of national education [2].

Essentially, efforts to improve the quality of education have long been a priority in the development of Indonesia's education sector, especially since the late 1970 s, when the government succeeded in introducing an education program for equal opportunities. Programs for quality enhancement in vocational schools is conducted. The teacher qualifications, the acquisition of textbooks, the reorientation of curriculum and the enhancement of services, the promotion of infrastructure and the extension of collaboration networks with the industrial world are all initiatives to enhance the standard of vocational schools. However, the success of these different attempts to improve quality has not been promising, since no substantial progress has been demonstrated by different metrics of education quality. The trend of globalization, the needs of society and the demands of increasingly fierce competition, on the one hand, require a high degree of commitment to quality education. Quality enhancement is a continuous capacity to deliver internal and external educational facilities in a better manner, demonstrating the ability to meet anticipated needs [3]. Meanwhile, Purwanto [4] suggests that educational curricula and programs, facilities, easy access, educational processes, resources and posteducation services are factors that contribute to school success in differentiation strategies. Of course, the more elements they own would enhance the framework of educational institutions.

According to Porter [5], one of the strategies that schools may design to sustain and enhance the competitiveness of schools is through competitive string. This competitive strategy is an attempt to find a desirable competitive position in an important region in which competition takes place. In order to 
win the competition, every school needs to devise the right strategy and position. Porter further clarified that the object of the competitive strategy is to promote a place where a school can best defend itself or positively influence these pressures against the forces of competitive pressure. In order to establish a secure defensive position (defendable position), an effective competitive strategy involving attack (offensive) or defense actions is required (defensive). Therefore, the secret to designing an effective plan is the need to evaluate circumstances or sources of power. In addition, Porter notes that there are three generic strategic tactics that can efficiently outperform rivals in competitive situations, namely the overall cost advantage, differentiation and emphasis [5]. This research focuses more on a concentrated approach, as each vocational school has distinct advantages in achieving its objectives.

The emphasis strategy is carried out by choosing a particular section or group of sections and adapting the strategy to specifically support this section or segment group. An agency focuses on gaining competitive advantage in its target segment by adapting its strategy for the chosen target segment, even though it has no overall competitive advantage [5]. An effective emphasis plan relies on a company that has strong potential for growth and that agency does not care about the success of other rivals. An institution can achieve a competitive advantage in the target customers it selects through the effective execution of a focus strategy, even if it does not have a large level of competitive advantage [6 and 7]. The emphasis is on the school's approach for focusing on a specific target market in educational institutions. This usually starts with the determination by educational institutions of market share. Three major classes are economically present in the society itself, namely the poor, the middle class and the well-off groups. Educational institutions can choose to assess market share based on the three major groups in society by looking at the requirements of the school itself as well including the necessary education funds [4]. In addition, Wijaya [8] notes that a focus approach is commonly applied to services that have specific features. With this emphasis approach, it is hoped that by enhancing the standard of education in schools, schools are still trying to think about the best way to improve consumer loyalty and fulfill the needs of clients, namely students. Quality of education is a detailed definition and features of internal or external educational facilities that illustrates the ability to fulfill the intended consumer needs [3]. You may apply the safety principles stated by Hansler and Brunel in Tjiptono and Diana [9] in the provision of customer satisfaction services, namely: (1) customer satisfaction; (2) respect for everyone; (3) fact-based management; (4) quality improvement.

By benchmarking, strategies can be carried out to enhance the quality of education. Benchmarking is a continuous search activity and the actual introduction of best practices that contribute to superior competitive results. Benchmarking is a way to go backstage and see the success of another business from the wings, where noticeable are all the stage tricks and hurried realignments [10]. Benchmarking is a comprehensive and ongoing evaluation process; an organization's business processes are continually evaluated and compared to business process leaders everywhere in the world to collect insights that can help the organization take steps to enhance results [11]. Benchmarking is an activity that establishes standards and objectives that will be accomplished for a certain period of time. Benchmarking is commonly used to monitor and enhance the quality of education and academic standards [12].

This implies that each school must devise a different way of doing benchmarking strategies, based on the opinion of the experts above to allow the school to continue to succeed and obtain consumer loyalty, obtain results that exceed the cost of differentiation and also prevent rivals from finding ways to duplicate the benefits that were adequately provided.

First, cultural change, namely benchmarking that encourages educational institutions to generate new, more achievable results, improving performance, namely benchmarking that helps educational institutions recognize such performance gaps in the collection of processes to be improved [11]. Third, to improve human resource potential, namely, to have a training basis, different parties recognize that there is a difference between what they do and what other persons do in other organizations. Meanwhile, according to Goetsch and Davis [9] benchmarking as a method of evaluation and assessment of the organization's operations or internal processes against those who are the best in their class, both from inside and outside the institution and Michael Paulus and Devie [13] state that there is an important and positive impact between benchmarking against organization.

The vocational high school in the Argamakmur district is in the middle of a community that generally provides gardening for their livelihoods, and there are many oil palm, rubber, and rice fields in the town. By cultivating agricultural seeds according to the needs of the local community, this school focuses on plantations, so that the products of the nursery that the school does can be spread to the local community. 


\section{METHODS}

This research uses a qualitative approach to research of a descriptive sort. Qualitative Descriptive Research is research that examines problems requiring an in-depth understanding of the time and situation in question carried out naturally and naturally in accordance with objective field conditions, without any manipulation, and of the data obtained, in particular, by qualitative data [14]. By describing, studying, and relating data based on what is revealed or defined by the informants, qualitative descriptive analysis puts forward data collection to get clarification on the issue to be posed in the form of an interpretation. Principals, administrators, students and school committees were the study respondents. By way of observation, interviews and recording, data collection techniques were carried out. Miles and Huberman used an integrated research model to interpret the collected data descriptively and qualitatively.

\section{RESULTS AND DISCUSSION}

In general, the improvement of the quality policy carried out by vocational schools first creates levels of school quality. By forming a school quality assurance standards team, this quality level is determined. By setting graduate competency goals for each subject region, this team is charged with making graduate quality expectations, so that assessment is easier. In order to evaluate the strengths and deficiencies of the school in terms of curriculum, teacher resources and administrative staff, the facilities owned to support the quality standard program, and then perform an overview of external problems and opportunities, the assessment of the school environment is based on the quality expectations set by the principal. The school should do that and an exercise schedule is structured to accomplish the agreed goals.

In general, the improvement of the quality policy carried out by vocational schools first creates levels of school quality. By forming a school quality assurance standards team, this quality level is determined. By setting graduate competency goals for each subject region, this team is charged with making graduate quality expectations, so that assessment is easier. It is necessary for all school members to recognize and carry out the presence of a vision and mission, so that all educational delivery contributes to achieving the vision determined by the school.

The formulation of this quality improvement strategy is carried out by Benchmarking with other schools that are considered to have good superior programs and have proven to have succeeded in achieving quality objectives through curriculum growth, namely by combining effective subject matter with user needs, it is intended that the graduates produced are in line with the needs of the community. In addition, this vocational secondary school also performs benchmarking with the relevant Ministry of National Education, namely the Ministry of Agricultural Education, in order to enhance the capacity of teachers and students in the field of vocational practice. The approach to the benchmarking strategy uses an oriented approach, namely to improve the quality of graduates and to concentrate on practical subjects in line with the advantages of this vocational school, in particular in the field of agriculture especially in the rubber and oil palm nurseries. A collaboration with the Bengkulu Utara National Education Ministry to practice good practices by bringing in these experts and practicing internships in rubber and oil palm plantations in North Bengkulu was carried out to support this policy with a benchmark.

The implementation of this relationship is very supportive and the school has a benefit in having experts in its fields to perform successful and superior rubber and oil palm seedling trials, which can then be distributed to communities in need because there is no plantation area for student practice at this school.

By enhancing the standard of teachers' learning through in-house training, the benchmarking strategy to help the achievement of the quality goal of graduates is implemented by bringing in resources from both the Ministry of Education and Bengkulu University who are qualified in the field of creative learning. Teachers who master this technical skill will inspire students to think actively and creatively, and are very supportive of achieving the implementation of learning in schools. Studentoriented learning that actively learns helps students to understand more easily the content being learned, the role of the instructor to plan learning facilities, and events that challenge and attract the thought of learners.

A competition program is carried out each semester in each subject between classes for the academic area, so that it can inspire teachers and students to participate so that their class can win more awards. It will increase excitement if the student where he teaches succeeds, likewise with the teacher. There is healthy rivalry from both students and teachers here because the school would offer prizes or incentives to those who succeed. Allied field teachers work together as a team to prepare creative learning plans that will be introduced to students, both in the content elements, learning media, learning techniques, so that each class receives not much different learning and the skills of 
the students are hoped to be the same. In the sense of developing the character of responsible, disciplined and religious students through the school, extracurricular coaching, both mandatory and optional, is carried out by designing extracurricular programs that are enjoyed by students such as athletics, tahfizh, scouting, arts. This extracurricular practice also seeks to compete in tournaments with other colleges, both internally between classes and abroad, with the goal of receiving an award trophy. A quality team is formed to assess the quality target program that has been determined by the school, and is charged with tracking the progress of program implementation and reviewing program implementation using performance metrics that have been compiled and accepted with the school quality assurance team.

The benchmarking approach helps quality goals that are part of the school curriculum to be accomplished. Through evaluating external factors to assess the strengths and limitations of the school and analyzing threats and opportunities, initiatives can be initiated. Moving on from this analysis, a change policy is then formulated and an implementation plan is developed to accomplish the predetermined program. The effectiveness of applying benchmarking through understanding the institution's own characteristics. There are various features of each organization. For an organization, these characters can become its own strengths. For those who are well aware of the character / state of the institution through an analysis of the institution's internal and external environment, benchmarking techniques must be enforced. The research that can be used is an analysis of SWOT. SWOT analysis is a method of analysis for determining an organization's internal and external influences [15].

External collaboration outside the school can be performed through the introduction of the benchmarking technique, it can also be done internally. In this report, through the introduction of internal school competitions between classes and between teachers, the benchmarking strategy was carried out internally by setting school quality objectives. This method is capable of fostering a balanced competition spirit and enhancing the standard of schools. The characteristics of a target that can be said to be fine, one of which is teaoriented, as reported by Wibowo [16]. This is consistent with the concepts of organizational structure design, namely the division of function. Pursuant to Stoner [17]. The division of labor is the division of the entire workload into a variety of fair and convenient tasks that individuals or groups may perform.
Professional enhancement must be consistently carried out in order to encourage a culture of quality work for and student of the school and build superior schools that are the benchmarking goals. The prerequisites for benchmarking, willingness and determination, linkage of strategic priorities, goals to be the best, openness to concepts, awareness of current systems, goods and services, recorded processes, useful in assessing performance progress, are according to Rahman [18]. In order to evaluate a systematic benchmarking method, the principal has a significant role. Thomas Luke Spreen [19], according to Savanam Chandra Sekhar [20], benchmarking creates improved learning opportunities, encourages innovation and brings useful change and gains organizations a competitive edge. And the benchmarking results data collected are reviewed at the end of the operation and shared with all individuals in an organization that has carried out benchmarks to get the support of all parties [21].

\section{CONCLUSIONS}

Benchmarking strategy for improving quality in vocational schools, district of North Bengkulu: beginning with a school environment analysis with a SWOT analysis as the basis, setting up a quality target program, establishing a quality assurance team, creative teacher learning preparation. Implementation of marking by improving the quality of schools with achievement class competitions every semester, standards for teacher work, apprenticeship and partnership programs, optimization of extracurricular activities, teamwork of teachers, building alumni networks, creating an evaluation team, and rewards for teachers and students.

\section{REFERENCES}

[1] Zaedun, A. (2011). Benchmarking Standar Mutu Pendidikan. Yogyakarta: Pusat Mutu.

[2] Depdiknas. (2005). Standar Nasional Pendidikan. Jakarta: Depdiknas.

[3] Sagala, S. (2013). Manajemen Strategik dalam Peningkatan Mutu Pendidikan, Bandung: Alfabeta.

[4] Purwanto, N. A. (2011). Strategi Bersaing Dalam Bisnis Pendidikan. ,Jurnal Manajemen Pendidikan, Vol.7 (1).

[5] Porter. (2007). Strategi Bersaing (Competitive Strategy): Teknik Menganalisis Industri dan Pesaing. Tangerang: Karisma Publishing Group.

[6] Hitt, M. A., Ireland, R. D., \& Hoskisson, R. 
E. (1997). Manajemen Strategis: Menyongsong Era Persaingan dan Globalisasi. Jakarta: Erlangga.

[7] Watson, G. (2007). Strategic benchmarking reloaded with six sigma: Improving your company's performance using global best practices. New Jersey, USA: John Wiley \& Sons Inc.

[8] Wijaya, D. (2008). Pemasaran Jasa Pendidikan Sebagai Upaya untuk Meningkatkan Daya Saing Sekolah. Jurnal Pendidikan Penabur. 11 (7).

[9] Tjiptono, F. \& Diana, A. (2003). Total Quality Management. Yogyakarta: Andi Offset.

[10] Omachone, V. (2005). Principle of Total Quality. New York: CSC Press.

[11] Jens, J. (2007). Fundamental of Total Quality Management. London: Taylor \& Francis.

[12] Ruswidiono, R. W. (2011). Peningkatan Mutu dan Benchmarking Perguruan Tinggi. Jakarta: Sekolah Tinggi Ilmu Ekonomi Trisakti.

[13] Paulus, M., \& Devie. (2013). Analisa Pengaruh Penggunaan Benchmarking Terhadap Keunggulan Bersaing dan Kinerja Perusahaan.
[14] Arifin, Z. (2012). Penenlitian Pendidikan Metode dan Paradigma Baru. Bandung: Remaja Rosda Karya.

[15] Kurniadin, D., \& Machali, I. (2012). Manajemen Pendidikan: Konsep dan Prinsip Pengelolaan Pendidikan, Jogjakarta: Ar-Ruzz Media.

[16] Wibowo. (2011). Manajemen Kinerja. Jakarta: Rajawali Pers.

[17] Wahab, A. A. (2011). Anatomi Organisasi dan Kepemimpinan Pendidikan. Bandung: Alfabeta.

[18] Rahman, T. (2013). Benchmarking. Jakarta: Universitas Esa Unggul.

[19] Spreen, T. L. (2017). Does Benchmarking Encourage Improvement or Convergence? Evaluating North Carolina's Fiscal Benchmarking Tool.Journal of Public Administration Research and Theory, Volume 27, Issue 4, October 2017, Pages 596-614.

[20] Sekhar, S. C. (2010). Benchmarking. African Journal of Business Management Vol. 4(6), pp. 882-885, ISSN 1993-8233.

[21] Soetopo, H. (2012). Perilaku Organisasi: Teori dan Praktik di Bidang Pendidikan. Bandung: Remaja Rosdakarya. 